New Zealand journal of industrial relations, 1991, 16, 255-272

\title{
From personal tragedy to social oppression: the medical model and social theories of disability
}

\author{
Martin Sullivan*
}

Over the last decade the medical model with its individualized, psychologized and medicalized account of disability has been rejected in favour of a sociological account that views disability as an oppressive social creation. In these later accounts, the focus shifts from individual impairment to the disabling effects of social organization and structures designed around, and for, non-disabled people. This paper compares and contrasts the conceptual and theoretical approaches of both these models. In the light of these models, disability social policy, particularly as it affects the employment of disabled people, is examined.

\section{Introduction}

Over the last 15 to 20 years there has been a profound change in the epistemological basis of the discourse on disability, as disabled people have increasingly set the agenda for, and undertaken, studies in disability. Prior to this, the medical model dominated with the disciplines of medicine and psychology providing the conceptual and theoretical framework through which disability was approached. Disability was thus viewed as primarily a medical concern of functional impairment, and the experience of disability as dependent upon a series of psychological adjustments. With its emphasis on functional impairments and individual adjustment to them, the medical model generated a view of disabled people as the pathetic victims of some tragic circumstance. According to Michael Oliver (1990), the resulting "personal tragedy theory of disability" has been so pervasive that it has provided the "grand theory" underpinning most studies on disability.

Disabled people clearly felt it was up to themselves to provide a critique of the medical model. Drawing on their own experiences and those of other disabled people, these writers developed a social theory of disability in which the social, economic, political and ideological structures of capitalism are examined for the roles they play in "producing" disability and disabled people.

In this paper I will compare and contrast the medical and social models of disability and then, in the light of these models, evaluate social policy pertaining to disability. Particular attention will be paid to the way policy shapes the employment patterns of disabled people. Before I proceed, a disclaimer.

Throughout this paper I have chosen to use the term "disabled people" rather than the term "people with disabilities". There is much debate over terminology within the disability community and amongst the predominantly non-disabled professionals that work with disabled people. It is argued that the "people with disabilities" declares the value of the person first, thus reducing the disability to a mere appendage. Whilst many professionals and disabled people have adopted the sanitized "people with disabilities", I

* Department of Sociology, University of Auckland. I would like to thank Zaiem Baksh, Peter Brosnan and Wendi Wicks for their comments on initial drafts of this paper. 
believe their position is becoming increasingly less tenable. Firstly, as the disability pride movement grows, disabled people are increasingly owning their disabilities and demanding acceptance as they are, as disabled people. To me, excusing one's self as "a person with a disability" indicates an implicit acceptance of "able-body" hegemony which defines disabled people as flawed and inferior. Also, the irony of a "disabled person" writing for a learned journal should not be lost. Secondly, many disabled people argue that the lived reality makes their disability more than an appendage, it is an essential part of self. In such instances, to talk about the person and the disability separately is nonsense.

\section{The medical model of disability}

The context in which the medical model of disability became established is eighteenth century Europe and the emergence of the Welfare State. In England, the Poor Laws marked the beginnings of the Welfare State in that they established an implicit system of obligation between society and individuals. Individual needs would be met through work; the State would meet the needs of those not in work. Since not all people were able or willing to work, the State was only obliged to meet the needs of those involuntarily out of work. Thus, categories of "deserving" paupers were created in the administration of welfare programmes: "In very early descriptions of welfare programmes in European towns [there is] only reference to special treatment for the aged and infirm, for lunatics and defectives, invalids ... and impotent beggars" (Stone, 1985, p.26).

Clearly these categories would be subsumed under the generic "disabled" today. But "disability" is a fairly modern concept associated with modern clinical medicine, and under the Poor Laws these were essentially legal categories. Accordingly, judgments about inability to work, or the legitimacy of an individual choice not to work, were made by priests, judges, juries, teachers or public officials without reference to physicians. This, however, was not an entirely satisfactory state of affairs. Traditional categories of welfare dependency e.g. age or widowhood, could be confirmed by disinterested officials with reference to public records of birth and death. Disability was always problematic as no single condition of "disability" was universally recognized, and because physical or mental incapacity could always be feigned for the secondary gain of welfare (Stone, 1985). What was required was an objective index to measure capacity to work, a means to quantify incapacity, a procedure whereby disability would be objectified in individuals and thus legitimate their claims to social aid. Medicine was to provide the solution to this dilemma.

Firstly, major changes in the medical concept of disease occurred in the nineteenth century with the discoveries of bacteriologists Pasteur and Koch. The resulting "germ theory of illness and disease" was to both absolve the individual from any responsibility for, or control over, his or her condition as well as to legitimate medicine as a science. Secondly, technological breakthroughs in the development of instruments such as the stethoscope, the ophthalmoscope, the X-ray machine and the microscope equipped physicians with an array of devices which gave them information about the body independent of patients' descriptions. These new diagnostic methods enabled the physician to assume the role of disinterested public official who could distinguish between genuine disability and feigned disability on the basis of objective, scientific measurement (Stone, 1985; Turner, 1987).

With these tools of legitimation, medical science was incorporated as an apparatus of the State that focused on disability purely in terms of individual, functional impairment and capacity to work. Thus, separated out, specialised institutions arose to care for disabled people; asylums for the mad and hospitals for the physically impaired.

The segregation of the physically impaired in institutions made possible 3 developments which greatly increased medical control over the lives of the "disabled". 
Firstly, etiology became the primary concern, and specialization permitted people with different types of disabilities to be placed in separate diagnostic categories (Hahn, 1987). Secondly, the hospital environment encouraged the growth of helping professionals such as nurses, physiotherapists, occupational therapists, social workers, counsellors, etc., so much so that today "there is almost no aspect of [a disabled person's] life for which there is no professional" (Finkelstein, 1980, p.11). Thirdly, greater numbers of physically impaired people survived as a result of successful developments in medical practises thus strengthening the connection between disabled people and institutions. These "survivors" were in turn made dependent upon the programmes of the professionals within institutions. And since these professionals "either work in organisations hierarchically dominated by doctors or have their professional practice structured by a discourse based upon the medical model" (Oliver, 1990, p.48), it was inevitable that the lives of disabled people were made subject to medical power.

Tentacles of medical power reached beyond the institutions to control the lives of disabled people as medical professionals were authorized by the State to gatekeep welfare disbursements to physically and mentally impaired people. Doctors, occupational therapists and social workers became involved in the allocation of financial benefits, in assessing individuals for specialized equipment such as wheelchairs and hearing aids, in deciding educational needs and measuring work capabilities and potentials (Oliver, 1990), in determining the type of living arrangements best suited for individuals, and in authorizing structural changes to homes at the State's expense. To receive statutory provision, disabled people were required to submit themselves to the medical gaze to have their "condition" validated. By virtue of this requirement, a particular perception of disability and disabled people became entrenched in the bureaucratic and public mind. The medicalizing of disability was complete.

Psychology has proved a natural adjunct of the medical model's tendency to define disability in terms of individual deficit. All psychological theories of disability share an assumption that the onset of disability does not just bring about physical changes, but also changes of mental function. A series of psychological mechanisms of adjustment have thus been identified (Cohn, 1961; Fink, 1967), or more appropriately borrowed from other areas such as death and dying, which an individual must work through before he or she can come to terms with his or her disability (Albrecht, 1976). For example, a study identified a 4-stage process involving shock, denial, anger and depression by which newly disabled paraplegics come to terms with their disability (Weller and Miller, 1977). Hence psychological studies tend to focus on the emotional management of the physiological and psychological implications of disability at an individual level (Sullivan, 1988).

The conceptual framework provided by psychological models of adjustment has been severely criticized on theoretical grounds (Finkelstein, 1980), methodological grounds (Oliver, 1981), and the grounds that it does not correspond with the actual experience of disability (Sutherland, 1981). Psychological explanations are also problematic in that by ignoring issues of social prejudice and institutional discrimination they treat the disabled individual as ultimately the source of any problem (Longman, 1987). From this perspective it is easy to see why medical and psychological explanations make such good bedfellows and why they have dominated the discourse on disability: not only do they both adhere to the same empirical "scientific" tradition, but both are also politically convenient insofar as they individualize and naturalize (i.e. accepted as unproblematic givens of the condition) the "problem" of disability.

It would be churlish not to acknowledge the vast improvements medical science and medical technology have brought to the lives of many disabled people. Previously disabling conditions can now be cured, prevented through vaccination (polio) or greatly ameliorated through surgical and physical medicine (spinal bifida, spinal cord injury). Unfortunately, the benefits of medical science have not come without cost; they have placed a mortgage over the lives of disabled people. Arguably the heaviest payments are 
extracted by the way in which medical science has shaped the social perceptions of disability and disabled people.

\section{Social perceptions engendered by the medical model}

Segregated in institutions, physically impaired people provided a pool of subjects for medical assistance, investigation and experimentation. Consequently, the medical model came to be accepted as the authoritative account of disability; an account in which disability was, until recently, defined almost exclusively from a medical perspective that focused on functional impairments (Hahn, 1987). It is not surprising therefore, that both society and disabled people became obsessed with disabled bodies and the degree to which they diverge from normative standards (Finkelstein, 1980). Or that physically impaired individuals have been conceptualized as being deficient - the victims of some lamentable happening or circumstance (Finkelstein, 1980; Sutherland, 1981; Oliver, 1983). This view has not only cast disabled people as tragic, pitiable victims, but also influenced most of the studies on disability by providing a ready-made "personal tragedy theory of disability" (Oliver, 1990).

Medicine has linked disability with disease and pathology. Hence, disability is seen to reside in individuals who are biologically flawed and thus negatively changed both physically and psychologically. Consequently, disabled people are perceived as not only looking different, but as being different in their cognitive processes, responses and actions. They must therefore be treated differently, approached with caution or controlled through exclusion.

Other responses flow from the perception of disability as a disease-like condition. Disabled people should be treated as if they are sick and should have extended to them the mature tolerance automatically given to a sick friend or neighbour. Alternatively, the disease-like taint surrounding disabled people often elicits very complex feelings of fear, revulsion, guilt and anxiety in the healthy (Gliedman and Roth, 1980).

Institutionalization removed disabled people from their families and communities making them variously objects of curiosity, fear and loathing. Isolation in hospitals fostered a perception of disabled people as being the passive recipients of aid; dependent, powerless and always needing non-disabled people to do things for them; disabled people become less than human in the eyes of the wider community. They became referred to as "invalids". That is, "in-valids", negations of what it is to be human.

Specialization has fragmented the disabled community into a variety of groups organized around, and divided by, the particularities of their conditions e.g. epileptics, tetraplegics. Instead of being united by the commonalities they share as disabled people, specialization has served to depoliticize disability by treating the entire social group as a collection of disabled individuals rather than as an oppressed group. It also depoliticizes by reinforcing the notion of disability as individual pathology. This in turn individualizes the "problems" faced by disabled people; thus naturalized, the problems become inherent to the condition - a concern for doctors or psychologists, not the broader social environment.

Notwithstanding the dominance of medicalized perceptions, a change is occurring within the social relations of disability. This change has been precipitated by disabled people as greater numbers are seen functioning independently in the community, by the growth of organizations of disabled people and the emerging group identity, and finally, by their spokespeople who are increasingly active in articulating their own perceptions of their situation. This state of affairs has prompted one writer to characterize disability today as a:

paradoxical situation involving the state of the individual (his or her impairment) and the state of society (the social restrictions which are imposed 
on an individual) ... Attitudes may be held towards the individual who is impaired, or toward the social barriers (Finkelstein, 1980, p.6).

In the preceding analysis of the medical model we have looked at one side of the disability paradox and how disability came to imply personal tragedy, passivity and dependency. The other side of the disability paradox, the social creation of disability, is examined in the next section.

\section{The social theory of disability: the social oppression/ creation model}

Over the last 15 to 20 years another model has arisen to challenge the distortions inherent in the medical model. This model, based upon the lived experiences of disabled people, rejects the individualized, psychologized and medicalized account for a sociological account which shows disability to be a social creation located within the institutionalized practices of society. In these later accounts the focus shifts from individual impairment to the disabling effects of social organization and structures designed around and for "able" bodies. A critique of the disableist ideology that operates to maintain these discriminatory structures is part and parcel of a social theory of disability.

Social theorists of disability begin with a re-definition of disability which involves a twofold classification:

Impairment is lacking part or all of a limb, or having a defective limb, organism or mechanism of the body; and disability is the disadvantage or restriction of activity caused by a contemporary social organization which takes no or little account of people who have physical impairments, and thus excludes them from the mainstream (Finkelstein, 1980).

This definition shifts the locus of disability from individuals, and locates it squarely in society and social organizations that discriminate. Following from this conceptualization, some writers see disability as a set of ideas, an ideology which maintains disableist structures. In this view, disability is no more or no less than "social oppression". Physically impaired people are oppressed by both atcitudes and the built environment which deny physical, intellectual and emotional access to the wider social milieu. In this oppressive process, physically impaired people are socially created (negated?) as disabled people.

However, this does not explain why physically impaired people are socially oppressed nor how they have been recreated as disabled people. Ideas and attitudes do not exist in a vacuum and do not oppress unless they have a material basis. So to move beyond idealism and idealist explanations of disability, a materialist analysis which considers the economic, social and political structures which underpin the ideology of disability is required. Building on his earlier work and that of others in the area, especially Finkelstein (1980), Michael Oliver presents the most comprehensive and theoretically developed materialist analysis thus far, in his The politics of disablement (1990).

Using historical materialism as a framework, Oliver argues that the perception and social location of disabled people depends upon the mode of production, the size of the economic surplus and how it is distributed amongst the population as a whole. From this viewpoint, Oliver shows how the oppression of disabled people is, firstly, a direct consequence of changes in the economic mode of production. In the cooperatively organized, pre-capitalist (feudal) mode of production and the cottage based industry of the time, the great majority of disabled people were not precluded from participating in the production process. For example, deaf people could learn agricultural tasks by 
observation, and blind people, without special training, could perform routine tasks involving tactile skills in familiar surroundings (Topliss, 1975).

However, the transition to capitalist factory production was accompanied by the rise of individual waged labour and the ideological construction of the "able-bodied" worker who could operate complex factory technology. This becomes important in relationship to disability for it is the construction of "able-bodied" and "able-minded" individuals which is significant: the ideological construction of the disabled individual follows as the antithesis of able-bodiedness and able-mindedness. Disabled people were subsequently expelled from the workforce to be segregated within their homes and, in the ideological climate of "able-bodiedness", disablement became a source of shame and disabled people a social problem. For those families who could not cope with their disabled members, particularly working-class families already under pressure in the new capitalist social order, institutional care became an option (Oliver, 1990).

For Oliver, the individualism underpinning capitalism is buttressed by the peripheral ideologies of medicalization and personal tragedy theory. Medicalization legitimates medical intervention and shifts attention to individual impairment; personal tragedy theory underpins social policy which aims to adapt disabled individuals to society rather than effecting structural change to facilitate their inclusion. Hence, in capitalist society, disability is defined by the hegemony of able-bodiedness which is constituted by the ideologies of individualism, medicalization and personal tragedy theory.

Oliver was able to show in his discussion on the cultural production of disability, that disabled people are not treated as inferior in all societies, nor at all historical points. The inferior position in terms of income, employment, education, housing or transport that disabled people occupy in capitalist societies is therefore, neither natural nor inevitable. It is the product of the individualism, medicalization and personal tragedy theory. And who benefits? According to Oliver, capitalism benefits for:

disabled people may perform an economic function as part of the reserve pool of labour and an ideological function in being maintained in their position of inferiority. Thus they serve as a warning to those unable or unwilling to work (Oliver, p.70).

While disability is a particular form of oppression (Abberley, 1987), it would be wrong to consider it one dimensional; it is in fact multi-dimensional. Many disabled people suffer the additional burden of racial and/or sexual oppression which structures their experience of disability in particular ways (Brown, 1985; Wicks, 1991).

Before I continue Oliver's political programme, I would like to point to a number of problems I have with his and similar analyses. Amongst my concerns are the tendency to romanticize disability and disabled people's lives in the pre-capitalist era, and to cast disability solely as a product of capitalism; to fudge the issue of physiology and degree of impairment; the tendency to treat the disability community as a homogeneous unit is also problematic. I am addressing these problems elsewhere.

\section{Oliver's programme of emancipation for and by disabled people}

In developing his social theory of disability Oliver uses a framework derived from historical materialism to show that the dominant view of disability as an individual medical problem is created by "the productive forces, material conditions and social relations of capitalism" (Oliver, 1990, p.132). However, in developing his political programme he rejects Marxism (p.25) and any possibility for a transition to socialism in the foreseeable future. Rather, he pessimistically predicts an extension of capitalist forces, conditions and relations of production in "post-capitalist" society. Notwithstanding this, Oliver is optimistic about the possibility for an improvement in 
the material conditions and social relations of disability in post-capitalist society. His optimism rests primarily upon the "rise of a strong, vibrant and international disability movement" (Oliver, 1990, p.132): a new social movement that will change the medicalized perception of disability to one of social oppression. Oliver's optimism ultimately rests therefore, upon a change in consciousness rather than on any change to the economic base.

Justification for this theoretical shift is provided by Oliver's acceptance of a "postmaterialist paradigm" in which he considers the new social movements within a framework derived from the work of Gramsci (1971). From this framework a consideration of 3 discrete areas is called for; the economy, the State and civil society, all given a sense of unity by the concept of hegemony. Oliver suggests that social transformation can be achieved for and by disabled people acting within the State and civil society. His 2-pronged programme is designed to counter the hegemony of "ablebodiedness" that unifies the economy, the State and civil society into a force which oppresses disabled people. Firstly, within civil society, disabled people must establish a strong disability rights movement with the objective of having disability accepted as a form of institutionalized social oppression like institutionalized racism or sexism. This will involve disability rights activists engaging in consciousness-raising activities, demonstrations, sit-ins and other forms of street level political action. Secondly, others will simultaneously develop a not uncritical relationship with the State and work within political and bureaucratic, State-funded institutions to (i) ensure a greater redistribution of resources to disabled people and, (ii) effect legislative changes that promote disability rights.

Crossing the borderline between the State and the economy will mean disabled people will have to renegotiate their relationship with organised labour. This will be a difficult process because labour will have to confront the disableism inherent in its appropriation of a hegemonic or privileged role in social transformation (Sutherland, 1981), and in its resistance to changing work-practices to facilitate the employment of disabled people (Oliver, 1990). From this perspective, we can see how disabled people are caught between the disableist and hegemonic practices of capitalist employers and organised labour. The former refuse to employ disabled people because they are not ablebodied; the latter, by prioritizing able-bodied labour, has never considered the position of people disqualified from being the producers of surplus value. Little wonder therefore, that Oliver confines his programme to consciousness-raising exercises in civil society, and to working within the State to gain disability rights and a greater redistribution of resources to disabled people.

This of course begs the question: how realistic is it for Oliver and disabled people to pin their hopes on the goodwill of the non-disabled, and in a resurgence of the Welfare State given the current domination of New Right ideology? Both Britain, the context from which Oliver writes, and Aotearoa-New Zealand have adopted New Right policies premised on the retrenchment of the State and the advancement of individual entrepreneurialism as solutions to the current economic crisis. The subsequent cuts in state spending - benefits last December; housing, health, education and welfare services in the 1991 Budget - have impacted heavily on those most dependent on those services, namely unskilled and low waged workers and beneficiaries - categories to which the majority of disabled people belong. If these cutbacks herald the advent of "post-capitalist society", then the likelihood of improvements in the material and social conditions of disabled people in late capitalism seems bleak, particularly when an "extension of capitalist forces, conditions and relations" is predicted (Oliver, 1990, p.132).

Marx (1976) argued that the capitalist dynamic depended upon ever increasing profits achieved by reducing the costs of variable capital i.e. wages and conditions. An important instrument for suppressing worker demands is the industrial reserve army, a pool of unemployed people waiting to fill the jobs of dissatisfied workers. Marginal groups like disabled people, housewives, immigrants and black people, complete the 
industrial reserve which permits employers to maintain high rates of profit. Further, disabled people and other exploited populations, are often "compelled to perform routine jobs that are neither readily mechanized nor regarded by capitalists as justifying the payment of prevailing wages" (Hahn, 1987, p.551). Finally, they are available as stopgap measures when labour shortfalls occur during times of prosperity or during wars when acute shortages of non-disabled labour creates a demand for other workers. From this view, disabled people perform an important economic function within the capitalist state; they maintain profit as part of the industrial reserve or by performing tedious work at low rates of pay. Under capitalism therefore, it is not in the interests of capital to maintain "the disabled" at much above subsistence level.

Together, the attacks on the Welfare State and the role of disabled people in the reserve army, call for a re-evaluation of Oliver's programme. Where his model breaks down is his departure from historical materialism to idealism. For Oliver to insist that at one particular historical point material conditions determined consciousness, and then to formulate a programme which relies on changing consciousness in order to change material conditions, demonstrates a remarkable philosophical and theoretical turnabout. In practice his programme may result in short term gains during times of economic expansion, but these will only be lost in times of economic crisis. (This point is developed below in the discussion on the State Sector Act). A programme that aims to permanently improve the lot of disabled people must not treat ideology as if it exists in a vacuum. It must address the material basis of ideology, namely the economic mode of production and issues related to the economic surplus. Issues such as who produces the surplus; why certain groups are systematically excluded from the production process; who owns the surplus produced; on what basis is it to be distributed throughout the population, must be addressed. Such a programme will, of necessity, include a rapprochement between disabled people and organised labour, as well as establishing links with women, black people and other minority groups oppressed by the mechanisms of capital. The development of collective strategies to transform the material basis of the ideology which divides each of these groups, both within and without, will then be possible. One can imagine that such a strategy will involve a transition from an economic mode of production organized for private profit to one organized for public good. For disabled people, the advantage of a collectivist approach is twofold: firstly, it is naive to think we can effect permanent change on our own and, secondly, the process of negating stereotyped images of disabled people will be advanced.

While Oliver's programme is questionable, the analysis underpinning his social theory of disability is of value. Although it was developed with reference to the British context, it still has explanatory power when trying to understand how disability is conceptualized in New Zealand: we have a heritage of British values, both countries share a Westminster style parliamentary and legal system and, for most of this century, a commitment to the Welfare State. In the remainder of the paper Oliver's model will be applied in an analysis of the social policy bearing on disability in Aotearoa-New Zealand. The primary focus will be on the ways in which the possibilities, employment patterns and location of disabled people in the labour market are structured by disability social policy. 


\section{Disability, social policy and employment}

Disability is essentially whatever public laws and programmes say it is (Hahn, 1987, p.182).

Disability social policy is articulated in legislation which defines disability in terms of individual pathology (Social Security Act 1938, Rehabilitation Act 1941, Disabled Persons Employment Promotion Act, 1960 (DPEP), Accident Compensation Act 1972) and/or physical and mental impairment (Disabled Persons Community Welfare Act 1975 (DPCW)). Having thus defined the problem, the public provision of treatment, rehabilitation and short- and long-term care of individuals within a medical setting was stipulated as the solution.

\section{Social policy 1: medicalizing disability}

Medical hegemony was established over disabled people via the Social Security Act which legally sanctioned medical intervention in their lives. Under the terms of the act, the "health and general welfare of the community" was to be sustained by medical intervention in those New Zealanders with "disabilities arising from age, sickness, ... and other exceptional circumstances". The "problem" of disability was thereby individualized, defined as arising from a personal situation, and shifted into the medical realm where, within the limits of technology, functional deficit was to be cured or reduced. The Act also provided for monetary compensation in the form of benefits to be paid to these unfortunate individuals.

Where medical intervention is not successful, the individual patient passes into a system of rehabilitation where he or she is counselled to live with his or her deficit. Vocational retraining in forms of work suited to the impairment reinforce the message that disability is an individual problem requiring an individual to adapt to society. Where an individual's deficit excludes him or her from open employment, sheltered employment is provided. Such programmes were first directed at disabled ex-servicemen (Disabled Soldiers Re-establishment Act 1930; Rehabilitation Act 1941) but in 1954 they were extended to civilians with the establishment of a National Civilian Rehabilitation Committee which later became the Rehabilitation League NZ (Inc). In a nationwide network of training centres, the League undertook the assessment, counselling and vocational (re)training of disabled people as well as providing sheltered employment for those incapable of full employment (Pirie, 1977; Bolt \& Heggie, 1982). Such orientation reflects the penetration of medical conceptions of disability into the rehabilitation process which presumes that the disabled person is unemployed because of a deficit; that a person's capacity to work is determined largely by his or her individual capabilities. Such an assumption may have had validity in an economy founded upon manual labour, but as Hahn (1986, p.126) observes "its relevance to an economy based primarily upon the provision of services or advanced technology might be subjected to increased scrutiny". More fundamentally, the "flawed individual" approach ignores the issues of architectural barriers, social discrimination, employer prejudice and directs energies towards restructuring the psychological and vocational behaviour of clients.

From this point of view, successful rehabilitation can be characterized as the lived expression of the ideologies of individualism and personal tragedy. In the process, more severely disabled persons are persuaded by medical professionals (doctors, nurses, counsellors, psychologists, occupational and physiotherapists, social workers) to accept medical explanations of disability and to blame themselves, not social factors, for the disabling consequences of their physical impairments. As medical explanations are internalized, disabled people are turned into docile subjects and are set up for exploitation in the labour market. Belief in their ascribed inferior status and capabilities is confirmed 
by the passivity with which disabled people accept high rates of unemployment resulting from employer discrimination, and the alacrity and gratefulness with which many will accept whatever employment is offering. It is not surprising therefore, to find disabled people concentrated in low paid, low skill jobs with no pathways to career development.

Having said this, it would be a mistake to assign gratefulness to all disabled people employed in menial, repetitive work. Many are, in fact, very disgruntled with their pay and working conditions, but are forced to work out of economic necessity and/or for the secondary gains of social contact and the status that comes with being in paid employment. Such people may well be colonized, but I feel it is a mistake for Oliver to overlook them. They may well come in contact with disabled activists who introduce them to the social creation model of disability. Liberated from their colonial shackles, they potentially provide (i) the nexus for a rapprochement with organized labour and, (ii) points of entry for disabled people to become actively involved in reorganization at an economic level. This raises several questions: why the need for a rapprochement with organized labour? what are the historical reasons for disabled people not having a higher profile in the union movement in Aotearoa-New Zealand? One answer lies in sheltered employment and the central role it has played in the "rehabilitation" of so many disabled people in Aotearoa-New Zealand.

\section{Social policy 2: the promotion of exploitation}

The Disabled Persons Employment Promotion Act 1960 (DPEP) approved sheltered workshops for civilians and allowed exemption from specific provisions in legislation, awards or collective agreement for organizations providing sheltered workshops for disabled persons. However, before granting approval to any organization the Minister of Labour (now Employment) was bound under section 5 to "consult" with unions, the national organization of employers and the national organization of workers. Depending upon how "consult" is interpreted, a number of ways in which disabled workers might have been viewed by the unions is suggested. On the one hand, "consult" could have been interpreted as "directive" by the Minister, leaving the unions little say in the matter. On the other hand, a Minister may well have consulted with the unions, which, in the interest of protecting their own workers' from under-rate disabled labour, complied with the Minister's "approval or recommendation". A third perspective, from a disabled person's point of view, interprets the provisions of the DPEP as logical given the uncontested dominance of the medical model of disability. The ongoing exploitation of disabled people in sheltered workshops merely confirms the complicity of the State, employers and labour in the oppression of disabled people. This interpretation is probably the most accurate, given that it is only in the last 10 years that disabled people in Aotearoa-New Zealand have collectively begun to challenge the medical model and to articulate their perspectives themselves.

However, there is reason to believe that the trade unions are beginning to take the concerns of disabled workers more seriously. This is evidenced by the appointment last year of a disabled person by the Auckland Council of Trade Unions to inform and coordinate union representation and activities for and with disabled workers. Another example demonstrates both the power the Act gives medically oriented organizations to exploit workers in their sheltered workshops and the changing relationship between organized labour and disabled people in Aotearoa-New Zealand.

Recent attempts by workers at an Auckland sheltered employment site to negotiate a modest increase in wages and conditions were met with a refusal on the part of the executive to negotiate. Frustrated, the workers approached the appropriate union for help which was readily forthcoming. A union representative subsequently spent hours in consultation with the workers on a number of occasions, listening to their grievances and explaining the benefits of union membership and the responsibilities that come with 
honouring awards. On learning of this, the executive called the workers to a meeting and told them that their involvement with a union was illegal under the DPEP Act and that, furthermore, they only had to give an hours notice before firing any person employed by the organisation. Defeated and intimidated the workers returned to work.

In presenting their ultimatum, the non-disabled, salaried executive implied that they too were victims of the Act and that it was state compulsion that denied workers union representation. There was no mention that an organization had to apply voluntarily to have the provisions of the Act applied to its workshops. A few weeks later the workers were awarded a slight increase in pay but were refused holiday and sick pay. This directs us towards a consideration of voluntary agencies as service providers in the disability field.

Role of the voluntary agencies At this point it is useful and enlightening to turn our attention to those born with a congenital disability, and the role voluntary agencies have played in structuring disability and the lives of disabled people in AotearoaNew Zealand. There has been a long history of inter-relation between statutory provision and the services offered by organizations such as the Crippled Children Society (now CCS), the Intellectually Handicapped Children Society (now IHC), the New Zealand Institute for the Blind, and numerous smaller agencies covering a variety of disabilities. The larger voluntary organizations have subsequently played an important part in structuring the social perception of disability and the lives of many disabled people in Aotearoa-New Zealand. For example, orthopaedic surgeons frustrated in their attempts to establish outpatient services and aftercare for children with polio, founded the Crippled Children Society in 1925. After polio was eradicated, they turned their attention to cerebral palsy, thus beginning the categorization and medicalization of physical disability in Aotearoa-New Zealand (Hunt, 1988). Thus, from its inception, the CCS has viewed and presented disability from a medical perspective which defines and objectifies individuals in terms of functional impairment. Efforts were not directed at changing social attitudes and the removal of barriers, but towards adapting impaired children to society: the focus was always on the impairment.

This approach has paid off for a number of individuals not in need of much adjustment. Excellent work has been done by voluntary agencies in educating and preparing for open employment many of their clients who fell into this category. They also provided invaluable support to many families struggling to provide for their physically or intellectually impaired children. However, another pattern emerges when listening to the experiences of people who passed through the residential and outpatient facilities provided by the larger organizations.

These were inevitably organized along medical lines, under-funded and largely dependent upon charity for operating costs. This ethos not only associated disability with poverty and inferiority, but also penetrated the cultures with disastrous consequences for residents. On the one hand, it inevitably attracted some staff and volunteers alike who, motivated by the "do-gooder mentality", came to work in the organizations where they could help the "pitiable" and "tragic" victims. On the other, it determined policy, for:

this [charity] model allows policymakers and providers of services to assume responsibility for decisions taken and methods used without any consultation ... The consequences of the system based on the notion that people requiring help are "patients" [is that] daily routines are structured round the needs of others, for example meals around kitchen staffing rosters and bedtimes to suit nursing shifts ... such a philosophical base deprives people of initiative, especially if they are dependent on others, as they are sometimes made to feel they must be grateful and not complain, or "rock the boat" (Hunt, 1988, p.784$785)$. 
Within the residential homes, the socialization of disabled children into an inferior and dependent status continued with the denial of education. Physically and intellectually impaired children alike were often considered not worth educating or, alternatively, provided with such inferior schooling that they seldom achieved beyond elementary levels. At school-leaving age, their vocational options were limited to specialized training in, say, packing pegs or folding cigarette cartons in the organization's sheltered workshops. Their dependence, passivity and sense of inferiority and powerlessness is complete. To the outside world, the inferiority of disabled people generally is confirmed by those who have been trained to perform routine tasks in sheltered workshops, as is the connection between physical and intellectual disability. More importantly, the tragic images of disabled people are authenticated and disability is perceived as an exclusively negative condition, something to be avoided at all cost.

But, as Hunt (1988) points out, there is another side to the charity ethic. Because voluntary organizations are dependent upon charity for funding, fundraising is an important activity. Frequently the methods used demean all disabled people. For example, the depiction of helpless and pitiable people, especially cute children, could always be depended upon to get the charity dollar. Today, in a sense of misenlightenment, fundraisers confront us with the equally demeaning image of a "supercripp" heroically confronting and coming to terms with her (crippled women are politically correct today) "challenge" - with the indispensable help of the organization of course! In either case, disabled people are exploited by the organizations purporting to help them. Most of the funds do, after all, go to provide supported employment for a bureaucracy and professional elite composed largely of non-disabled people.

From the above, we can see the pivotal role voluntary agencies have played, and still play, in structuring the social perception of disability and the lives of people either born disabled or disabled early in life. Caught at an early age in a closed system of long-term residential care-inferior education-dependence-sheltered employment-exploitation, these people have little chance of resisting dominant conceptions. Many cannot help but be colonized by the implicit messages contained within the practices consequent to medical explanations of disability: their physically impaired bodies have been worked upon to produce dependent, passive, disabled subjects.

However, it would be misleading to characterize the voluntary organizations as rogues operating without social approval. Succeeding governments have been happy for these institutions to fill in the gaps created by their under-funding of public provision; there has been no ground swell of outraged public opinion demanding a better deal for disabled people. Rather, the people of Aotearoa-New Zealand have been happy for, some would say demanding of, the voluntary agencies to provide the repositories for the disabled rejects of society; for the "children" who never become adults and who are best sheltered in segregated residences and workshops. From this perspective, the voluntary organizations and the institutional care they provide, are best understood as the products of the disableist hegemony which defines disability and consists of the interrelated and interdependent ideologies of individualism, medicalization and personal tragedy theory.

\section{Social policy 3: flirting with social theories of disability}

The Disabled Persons Community Welfare Act 1975 (DPCW) contains a mixture of provision based on medical and social conceptions of disability. It defines disability in terms of individual pathology and makes provision for the rehabilitation of individuals so afflicted. In a departure from the medical model, the social issue of access is addressed in 2 ways. First suspensory loans may be granted to carry out alterations to make a disabled person's home accessible. Second, building code 4121 made it illegal to erect physically inaccessible buildings for public use in public space. 
However, Code 4121 has been honoured more in the breach through exemption and lack of enforcement (Hunt, 1988, p.789) raising serious questions about the faith in which the Act was passed. Notwithstanding this, the provisions of the DPCW Act mark a substantial conceptual change. Inaccessible public buildings were recognized as a key source of disability; they compounded the disabling effects of functional impairment. Within limits their construction was outlawed.

\section{Social policy 4: legalising the oppression of disabled people}

With the DPCW Act, the means to eliminate architectural barriers to the employment of disabled persons in public space was now available. However, the means to remove attitudinal barriers have still to be enacted. Under the Human Rights Commission Act 1977 discrimination on the grounds of sex, marital status, and religious and ethical belief is unlawful. By omission, this Act legalizes discrimination against physically impaired people, especially in the labour market. In my own research, I have uncovered blatant instances of employer prejudice, discrimination and exploitation: the person who was refused employment on the grounds that her facial paralysis would "frighten clients"; of the person who uses crutches seeing "No in employers eyes as soon as they saw the crutches"; and the paraplegic who had to prove himself by working 3 weeks without pay before been put on the payroll.

The years of work put in by disabled people to have this situation remedied appear to be paying off. A Bill which will combine the Race Relations Act 1971, the Human Rights Commission Act 1977 and extend human rights to disabled people has been introduced to Parliament.

\section{Social policy 5: the State Sector Act 1988 - incorporating a social theory of disability.}

Equal employment opportunity (EEO) policy had been developing within the State sector since 1983. In 1988 it became mandatory under the State Sector Act for government departments to develop and implement EEO programmes. Five target groups - Maori, women, Pacific Island people, people from ethnic minority groups, people with disabilities - were identified as needing specific programmes which should aim to identify and eliminate all aspects of policies, procedures and other forms of institutional barriers that cause or perpetuate inequality in the employment of persons or groups of persons (State Services Commission, 1990, p.5).

Under the Act, departments were required to publish each year their EEO programmes, as well as ensure compliance with it; a summary and an account of the extent to which the department was able to meet the requirements of the EEO programme must also be published in annual reports. The promotion and development of each department's EEO policies was to be monitored by the State Services Commission (SSC). What the State Sector Act intended was the removal of impediments to State employers choosing the best person for the job, and the enhancement of State sector efficiency by providing the structures for managers to make the most of the skills and potentials of all staff.

In relation to disability, the State Sector Act 1988 is potentially the most progressive piece of legislation passed in our history. It provides mechanisms for organizational change which, theoretically, will see the elimination of disabling structures and facilitate the recruitment and career development of physically impaired people in the State sector. EEO provisions were extended to the private sector by the Employment Equity Act 1990 . However, the Employment Equity Act was repealed shortly after the National Government took office in November 1990 . Led by the 
Employers' Federation, the argument for repeal had turned about the "equal pay for work of equal value" debate, and the threat this would pose to profit margins and the accumulation of capital.

Although I have argued elsewhere that material circumstances determine the general character of consciousness historically, Peter Leonard (1984) reminds us that there is, at any given point, a dialectical relationship between them. He argues that "states of mind, intentions, can also change material circumstances, though always within historically determined limits such as the availability of resources and level of scientific development" (Leonard, 1984, p.25). Since Disability-EEO (D-EEO) began as an idea vritten in law, then the degree to which it has become a "state of mind" in the public service, and the extent to which the material circumstances of disabled people in the State sector have improved, are worth examining. This can only be accomplished within a general assessment of EEO.

In her review of EEO and State sector reform, Marianne Tremaine (1991) argues that the goals of EEO directly oppose the methods and direction of reform in the State sector. Theories espousing the uninhibited activity of the market as the best way of achieving desired goals have been the main driving force behind State sector reform. Public servants who formally administered rules were required to metamorphose into managers that take responsibility for the decisions they make. Opposing the free-market thrust, from a much weaker position, are EEO policies premised upon liberal assumptions of market intervention in the pursuit of equality for disadvantaged groups.

In the prevailing climate of efficiency, effectiveness and economy, Tremaine details the reluctance with which managers will divert scarce resources to implement EEO programmes. Window dressing has therefore been the name of the game with departments publishing EEO programmes but under-resourcing the execution of those plans. "Managers have," according to Tremaine, "made the assumption that measures of their success will give less weight to EEO than to the other three Es" (Tremaine, 1991, p.364).

Notwithstanding this, Tremaine says that the idea of EEO is widely understood throughout the public sector. Put another way, we could say that public sector consciousness had changed in regards to EEO. In seeking an answer to the question, "Have solid improvements occurred?", Tremaine turns to the target groups:

it is not the plan itself that matters, but the progress the plan makes possible ... EEO works almost as a smokescreen, hiding the lack of activity behind bureaucratic structures and procedures. Some would say that EEO has done no harm but little good. Others would say that EEO has provided a useful appearance of reformist activity, while masking the reality of reactionary conservatism and inaction (Tremaine, 1991, p.365).

With regards to D-EEO, Tremaine depressingly notes that departments moving towards corporatization do not want to employ disabled people, and that, overt discrimination against health impaired employees and those with disabilities was increasing (Tremaine, 1991, p.363).

From Tremaine's account, it seems clear that under-resourcing has meant that EEO has lacked a solid material base and remains mere ideology. As evidenced above, for some target-group members, EEO has become oppressive insofar as it promised so much but has delivered relatively little. Also, EEO is threatening to non-target group coworkers who mistakenly believe that EEO implies special rather than equal treatment for target group members. This can produce tensions and jealousies between the 2 groups as well as providing subversive and erroneous explanations as to why target group members might be advancing in their careers. In short, given the highly competitive and marketoriented ethos prevailing within the State sector, EEO could be seen as damaging the very people it was designed to help. 
Tremaine's assessment has been criticized for imbalance by people closely associated with EEO. In their opinion, she is overly negative primarily because she did not consult widely enough with people involved in the implementation of EEO throughout the State sector, and also for using selected informants. They highlight not only the training of general staff in EEO issues, but also the university scholarships, senior management and career development programmes, and time off for networking activities, as significant gains already in place for target group members. They direct attention to departments such as Social Welfare, Education and the SSC where EEO has become an important part of departmental culture. EEO coordinators argue that together these structures represent real and significant advances which Tremaine has overlooked. However, disappointment is expressed over the exceedingly slow pace of change, and also broad agreement with Tremaine's assertion that issues of economy are generally given priority over EEO.1

Anecdotal evidence also suggests that D-EEO has been hit the hardest by the new managerialism. This occurs at 2 levels. First, at an ideological level, the pervasive and deep-seated ideology of able-bodiedness negates disabled people in all situations (see SSC's census on ethnicity and disability, 1988). Further evidence of this is to be found in the popularity of Mainstream, a programme in which the SSC subsidises the wages of disabled people for the first 5 years. This shows that, by and large, government departments will only employ disabled people if they are paid to do so. Further, it implies that departments do not believe that disabled people can perform, and that, more properly, they should be the recipients of charity. Also, disabled people are often arbitrarily discounted from promotion on the grounds of efficiency and effectiveness. My informant was not surprised, therefore, by the fact that within the State sector most disabled people are confined to repetitive, basic grade positions with minimal prospects for further training and career development.

Secondly, at a material level, D-EEO appears to be carrying a lot of the "can" for financial restraint. For example, it is a bitter irony that the Justice Department affords full time advocacy for all target groups except disability. It is assumed common practice to similarly downgrade D-EEO in other departments. Also, relatively fewer resources in the form of scholarships and courses in career development are available for the disability target group.

Returning to Leonard's thesis that states of mind and intentions can change material circumstances providing resources are available within historically determined limits, then the evidence suggests that it is the wrong time for D-EEO. Wrong, because over the last 7 years New Right ideology has dominated in all sectors of the State, building an ethic and culture of competitive individualism in which "efficiency" dominates as an objective over "equity" (Peters and Marshall, 1990). In this climate, D-EEO personnel wage an uphill battle against managers who, while supporting EEO "in principle", are not prepared to release the resources necessary to turn principles into material reality. At this particular point in the State sector's history, it is obvious that "states of mind and intentions" are not sufficient to radically change the material conditions of employment for disabled people.

\section{Reflections on disability EEO}

Together the State Sector Act and the Employment Equity Act provided the mechanism for the elimination of some of the major social structures which transform physical impairment into oppressive disability. While it was not "up-front" disability social policy, the State Sector Act represents a quantum leap forward in the reconceptualization of disability: it confers legal status on the notion that disability is the product of social processes and social organization. Further, EEO policy has the 
potential to infect and change the way people think about disability by changing their practises in that important area of everyday life - the workplace. With organizational change and the provision of technology (State Services Commission, 1990, p.20), physically impaired people would have been incorporated into the mainstream of daily life as independent, adult subjects. It is tragic therefore, that the Employment Equity Act has been repealed and that, within the State sector, under-resourcing has denied D-EEO a material base ensuring it remains largely a "state of mind".

My earlier criticism of Oliver is born out by the path EEO, especially D-EEO, has followed in Aotearoa-New Zealand. It demonstrates that while a capitalist state can change laws in favour of oppressed groups, laws will only produce positive material change so long as they do not threaten the private accumulation of capital. For this reason, one would have expected EEO to have been enthusiastically and fully implemented in the State sector where the notion of public service has traditionally taken priority over turning a profit. However, the ascendency of the New Right has transformed the public sector so that increasingly it resembles the capitalist workplace where, according to Mandel:

a worker cannot be seen as a human being endowed with elementary rights, dignity and needs ... He [sic] is a 'cost element' ... constantly and exclusively measured in money terms, in order to be reduced to the utmost. Even when 'human relations' and 'psychological considerations' are introduced into labour organization, they are all centred in the last analysis upon 'economies of cost' (Emphasis added; Mandel, 1976, p.65)

The italicized portion of the above quotation is prophetic of the course D-EEO has followed in Aotearoa-New Zealand. It also confirms my view that any programme aimed at permanently improving the material conditions of disabled people must address the economic mode of production and the ideologies that mask the contradiction between socialized production and the private, capitalist form of appropriation. Without changing the material conditions that generate the organic ideology of individualism, and the arbitrary ideologies of medicalization and personal tragedy theory, disabled people will remain oppressed. Whether that oppression continues to take the form of material and social depravation, as at present, or is expressed as dependency upon the largesse of capital to support EEO and better than subsistent welfare provision, remains to be seen.

\section{Summary and conclusion}

Both the medical and social models of disability are best understood as products of the modern capitalist era. The medical model evolved as an instrument of the Welfare State to separate out paupers deserving of aid. Thus the focus was on individual functional impairment and inability to work. The subsequent provision of aid in the form of medical and institutional care had the effect of linking disability with disease and pathology while isolating disabled people from their communities. Concomitant with this approach was a social perception of disabled people as pitiable, dependent and tragic victims of fate deserving of charity.

In contradistinction, the social model reconceptualizes disability as a social creation, and disabled people as a minority oppressed by social, political and economic institutions which privilege "able" bodies over disabled people. A materialist, social theory posits that disabled people have been created by their exclusion from capitalist production which demands agile, individual wage labour to operate complex machinery in industrial processes. The exclusion of disabled people is legitimated by the ideologies of individualism which promotes the competitive, independent and property owning individual, medicalization which sanctions medical intervention, and personal tragedy 
theory underpinning social policy which aims to adjust impaired individuals to social institutions. Together, the ideologies of individualism, medicalization and personal tragedy theory constitute the hegemony which defines disability in capitalist society as the antithesis of normality, able-bodiedness and able-mindedness.

\section{References}

Albrecht, G. and Levy, J. (1981) Constructing disabilities as social problems. In G. Albrecht (ed.) Cross National rehabilitation policies: a sociological perspective. London, Sage.

Bolt, R. and Heggie, E. (1982) Report of the Rehabilitation Committee. Wellington, Department of Social Welfare.

Brechin, A., Liddiard, P. and Swain, J. (1981) (eds.) Handicap in a social world. London, Hodder \& Stoughton.

Brown, O. (1985) To incite insight: gender and disability. Race, gender, class 2:11-19.

Finkelstein, V. (1980) Attitudes and disabled people. New York, World Rehabilitation Fund.

Gliedman, J. and Roth, W. (1980) The unexpected minority: handicapped children in America. New York, Harcourt Brace Jovanovich.

Hahn, H. (1986) Public support for rehabilitation programs: the analysis of US disability policy. Disability, handicap and society, 1(2):121-137.

Hahn, H. (1987) Civil rights for disabled Americans: the foundation of a political agenda. In A. Gartner and T. Joe (eds.) Images of the disabled, disabling images. New York, Praeger.

Hahn, H. (1987a) Advertising the acceptably employable image: disability and capitalism. Policy studies journal 15(3):551-570.

Hunt, R. (1988) People with disabilities. In Report of the Royal Commission on Social Policy IV:767-804.

Legal Information Services (1982) The law and physical handicap. Auckland, Legal Information Service.

Leonard, P. (1984) Personality and ideology: towards a materialist understanding of the individual. London, Macmillan.

Mandel, E. (1976) Introduction. In K. Marx Capital Volume 1. Harmondsworth, Penguin.

Oliver, M. (1981) Disability, adjustment and family life. In A. Brechin et al. (eds.) Handicap in a social world. London, Hodder \& Stoughton.

Oliver, M. (1984) The politics of disability. Critical social policy 11:21-31.

Oliver, M. (1986) Social policy and disability: some theoretical issues. Disability, handicap and society $\mathbf{1}(\mathbf{1}): 5-17$.

Oliver, M. (1990) The politics of disablement. London, Macmillan.

Peters, M. and Marshall, J. (1990) Children of Rogernomics: the New Right, individualism and the culture of narcissism. Sites (21):174-191.

Pirie, A. (1977) Rehabilitation: New Zealand's handicapped policy. In G. Palmer (ed.) The welfare state today. Wellington, Fourth Estate Books. 
State Services Commission (1990) The invisible minority: a report of the Policy Development Working Group on the Employment of People with Disabilities. Wellington.

Stone, D. (1985) The disabled state. London, Macmillan.

Sullivan, M. (1988) The philosophies underlying the rehabilitation of traumatic paraplegics and tetraplegics: a review of the literature. Auckland Medical Research Foundation (Unpublished paper).

Sullivan, M. (1989) Ordinary people, ordinary lives? A sociology of paraplegia. Auckland Medical Research Foundation (Unpublished report).

Sutherland, A. (1981) Disabled we stand. London, Souvenir Press.

Topliss, E. (1975) Provision for the disabled. Oxford, Basil Blackwell and Martin Robertson.

Tremaine, M. (1991) Equal employment opportunity and state sector reform. In J. Boston et al., Reshaping the State. Auckland, Oxford University Press.

Turner, B. (1987) Medical power and social knowledge. London, Sage.

Wicks, W. (1991) Women with disabilities: some aspects of invisible lives. New Zealand journal of industrial relations 16(2):281-290. 